Jan Dvorsky - Jaroslav Belas - Ivana Novotna - Martin Fero - Zora Petrakova

\title{
QUALITY OF BUSINESS ENVIRONMENT OF THE SME: A SECTORAL VEW
}

The aim of the article is to find out differences in the perception of selected factors that determine the business environment among selected groups of small and medium-sized enterprises (SMEs), divided according to the sector of the national economy they belong to. The first group included SMEs from the sector of transport and services. The second group included SMEs from the construction, manufacturing and agriculture sectors. The questionnaire was completed by 459 SMEs in the Czech and the Slovak Republics. To evaluate the formulated hypotheses, the Chi-square test and the Z-score were used. The case study showed interesting findings. The SMEs in transport and services perceive the competitive environment as more acceptable than the SMEs in construction, manufacturing and agriculture. In addition, the SMEs in transport and services are of the opinion that customers accept prices of their products and services to a greater extent than the SMEs in construction, manufacturing and agriculture. There are also significant differences between selected groups of SMEs in assessing the quality of the judicial system in commercial law and the view that the current level of macroeconomic indicators supports entrepreneurship and creates interesting business opportunities. The national economy sector is not an important criterion in assessing financing, the family environment, R\&D infrastructure, the quality of the business environment or the quality of education. The paper brings interesting findings and new incentives for small and medium-sized enterprises; for organizations supporting the business environment; for further research and discussion on the cross-sectoral assessment of the business environment quality and its important factors.

Keywords: transport, national economy, SME, case study, Czech Republic, Slovak Republic

\section{Introduction}

Continuous changes in the business environment are forcing businesses to make permanent changes and innovations [1]. The ability of an enterprise to adapt to continuous changes in the business environment depends on its ability to adapt business objectives to conditions in the business environment [2]. Attitudes of owners and top managers towards determinants of the quality of the business environment are a valuable source of information for state, private and non-profit organizations. However, the primary beneficiaries are the small and mediumsized enterprises themselves, which can benefit from the knowledge gained in managing SMEs [3-4]. The structure of SMEs by sector of the national economy is one of the criteria that can cause different perceptions of factors determining the quality of the business environment as well as the perception of the quality of the business environment itself [5]. The sectoral view of the assessment of business environment quality factors by the SMEs in the transport and services sector provides important information not only for the companies concerned [6-7].

The article deals with the detailed comparison of evaluation of selected factors of the quality of the business environment by the group of the SMEs from the transport and services sector in comparison to the SMEs from the construction, manufacturing and agriculture sectors. The subject of comparison consists of selected economic, legislative, social, technological factors and competitive environments. The case study was carried out in 2017 and 2018 on a sample of 459 small and medium-sized enterprises in selected sectors of the national economy.

The article has the following structure. The first part presents current knowledge in the segment of small and medium-sized enterprises in given sectors of the national economy. In the second part, the aim of the article is determined; statistical hypotheses are formulated; methodology of data collection and sample structure of respondents and statistical methods used are presented. The next section presents the most important empirical results of the case study and evaluation of statistical hypotheses. The discussion summarizes the most important outcomes and compares the results to conclusions of articles from other authors in a similar field of research. In conclusion, there are limitations of the results as well as the future direction of research.

\footnotetext{
Jan Dvorsky ${ }^{1, *}$, Jaroslav Belas ${ }^{1}$, Ivana Novotna ${ }^{2}$, Martin Fero ${ }^{2}$, Zora Petrakova ${ }^{3}$

${ }^{1}$ Department of Business Administration, Faculty of Management and Economics, Tomas Bata University in Zlin, Czech Republic ${ }^{2}$ Department of Languages and Humanities, Faculty of Materials Science and Technology, Slovak University of Technology Trnava, Slovakia

${ }^{3}$ Institute for Forensic Engineering, Faculty of Civil Engineering, Slovak University of Technology, Bratislava, Slovakia

*E-mail of corresponding author: j1dvorsky@utb.cz
} 


\section{$2 \quad$ Literature background}

The business environment or the quality of the business environment is a broad term. The term business environment is used by the United Nations Conference on Trade and Development (UNCTAD). Formankova, Vajcnerova, Ryglova, Chladkova, Stojanova and Adrasko [8] state that the quality of the business environment is primarily determined by national legislation and national economic aspects that ultimately affect all the sectors of the national economy. In general, one can generalize that the SMEs are very sensitive to quality of the business environment.

The quality of the business environment plays an important role in the national economic sector - in the country's economic system [9-10]. This concept and its certain measurement or evaluation depend on values of the individual components. According to Kozubikova, Kotaskova, Dvorsky and Kljucnikov [11], the following factors are the legal form of the enterprise, the business activities of the corporation, the sources of financing (if at all and to what extent the corporation uses these funds), market, taxation and domestic taxation rate in the country, the rate of economic growth and development, the rate of inflation, the legal system in the country, the nature of accounting rules, social values, international factors (harmonization factors in certain areas), but also the country's culture and others [12]. This is also due to internal factors, e. g. property-legal relations in the company, activity of the corporation - e. g. in the context of corporate social responsibility, etc. Civelek, Kljucnikov, Dobrovic and Hudakova [13] also focus on the entrepreneur's personality in terms of their creativity and ability to be or to become an entrepreneur. Probably the oldest form of measuring the quality of the business environment in different countries is the Competitiveness Index of the Countries, published by the World Economic Forum (WEF).

In assessing the quality of the business environment, Viturka [14] assigns the greatest importance to business factors. Their partial factors are the proximity of the market - the geographical location of regions in interaction with the economic potential of the best available markets, the factor of concentration of major companies - in the context of location of major customers represented by economic or non-economic entities, presence of foreign enterprises - assessing the positive impact of foreign investment on integration of the host country into the global economy and the factor of supported services - higher demand for highly specialized services (Knowledge Intensive Services).

In the context of small and medium-sized enterprises (SMEs), their role is considered by many authors to be very important in the effective functioning of the economic system [15-16]. Chladkova [17] states that SME share unique characteristics that are determined by their nature and that also enable them to take a special position in the economic system. On the one hand, the SMEs generally have limited capital resources that adversely affect corporate governance and development, on the other hand, these companies are very flexible in responding to changes that occur in the economic system or they operate in a sector that is not of interest to large enterprises.

Transport has several functions. According to Eisler [18], in addition to its dominant function, which is transport or the movement of goods and persons, it further has a stimulating function, reflecting investment in transport infrastructure, which ultimately initiates the country's economic growth, the social stabilizing function - Fabus and Csabay [19] is of the opinion that transport has a significant political-social dimension and each disorder - the mismatches have a significant impact on the stability and development of the economy and society. Another function is the substitution function - e.g. with the Just in Time system in place, it replaces storage in the context of freight transport. The supply of transport is also closely related to other services, especially tourism, where it affects the structure of consumption and the size of services.

Surovec [20] further states that transport must, in addition to its main function - ensure the transport demand of society, contribute optimally to the national economic development and to the growth of the population living standard. This effect will only be achieved if the transport is understood as a coherent system involving all the types of transport of persons and goods. Novack, Gibson, Suzuki and Coyle [21] cite a well-functioning transport system as a requirement of an economically developed country. Transport is, according to authors, based on the historical, economic, social and political perspective, the most important industry in the world.

Novack, Gibson, Suzuki and Coyle [21] also draw attention to the negative aspect of malfunction or insufficient functionality of the transport system, which causes frustration of population and with it possible economic losses. In the case of a well-functioning system, there is an opportunity and reward for each user in different forms. Transport plays an important role in helping to bridge the gap in demand and supply as a part of a massproduction approach. Looking at services, many authors unite in their definition. For instance, Tuckova [22] defines service as an activity, or the advantage offered by one party to another, which is essentially intangible without customer ownership. According to Tuckova [22], the customer buys only the right to perform the service. Service production may or may not be associated with a particular tangible product. In addition, the author presents the features of services towards which the individual opinions of the author are converging. According to Bryson and Daniels [23], these are the following: intangible, inseparability, heterogeneity, difficulty in expressing value, destructibility (services cannot be deferred - stored, e.g. missed flight) and the impossibility of ownership.

Research and innovation are moving at a high pace. Product innovations go hand in hand with development of services and the constant impetus for more specific and knowledge-intensive services - services that require obtaining the knowledge needed to deliver them. Bryson and Daniels [23] classify Knowledge Intensive Services as 
services where some greater knowledge of the selected field to which the service relates is required, e.g. in the context of scientific and technical knowledge, research and development activities, etc. Those services require people with higher education and professional qualifications who can provide the client with a solution to their complex or narrowly specific needs. Those services play an important role in the innovation process of companies as these activities maintain interaction with the knowledge providers [24].

The constant diversity of services requires their arrangement - classification according to certain characteristic groups based on common features. Bryson and Daniels [23] defines division of services e. g. by nature of activities (NACE classification), by function performed (production, distribution, personal and social services), by mode of implementation (market services, social and economic needs), by target services market, by COPNI classification (classification of services by purpose).

\section{Aim, methodology and methods}

The aim of the article was to find out differences in perception of selected factors that determine the business environment among selected groups of small and medium enterprises (SMEs) according to the sector of the national economy. The first group included the SMEs from the transport and services sector $(\mathrm{T}+\mathrm{S})$. The second group included the SMEs from the construction, manufacturing and agriculture sectors $(\mathrm{C}+\mathrm{M}+\mathrm{A})$. The authors of the article assume that the perception of top managers or owners of the SMEs (herein after as respondent) to the evaluation of selected factors will be different.

During the calendar years 2017 and 2018, more than 17,200 SMEs from the Czech and Slovak Republics were asked to complete an online questionnaire. The total number of addressed SMEs represented more than $5 \%$ of all the SMEs in selected countries (CR: 9,400 SMEs, SR: 7,800 SMEs). The respondents were approached with the Bisnode Albertine database (CR) and the Cribis database (SR) by random sampling. The basic criterion for determining the total set of SMEs in selected countries was the number of employees of the enterprise (from 1 to 250 employees). The number of respondents who responded positively to the application was 641 SMEs (3.7\% return on questionnaires). Respondents were addressed by e-mail with a structured request to fill in a questionnaire. The questionnaire consisted of 82 assertions. The questionnaire was created in two versions according to the nationality of the respondent. The questionnaires are available on the following websites:

\section{Czech version:}

https://docs.google.com/forms/d/e/1FAIpQLSdTbrl5o KX93-hFY2deUAOYeWHWgI-tBa3zPape_FiJAmI-Dg/ viewform

\section{Slovak version:}

https://docs.google.com/forms/d/1_H7WSPiVJZkEXdQ x3VIGV0iJ_4ppDKRIQMXL6F8Vn-4/edit

The questionnaire was divided into three parts: $i$ ) socio-demographic characteristics - region of operation of the enterprise, national economy and size of enterprise; gender, age and educational attainment of the respondent; ii) business environment factors - economic, political, social, technological and competitive factors; iii) business environment quality contentions (QBE). The questions in the questionnaires were randomly formulated in order to really find out the respondent's opinion. The questionnaire also contained a control question to prevent the questionnaire from being filled by computer. The authors of the article evaluated 26 assertions (31.7\%) from all the questionnaire assertions to fulfil the objective. Respondents were able to comment on the claims by one of five options: totally disagree (A1), disagree (A2), cannot answer (A3), agree (A4) and totally agree (A5). The following arguments were the subject of the examination of attitudes:

F1: Macroeconomic environment: I evaluate the macroeconomic environment as friendly for business activity (F11); the state of the macroeconomic environment in our country promotes business start-ups (F12); the current macroeconomic environment supports innovative business activities (F13); the current level of basic macroeconomic variables (GDP, employment, inflation) supports entrepreneurship and creates interesting business opportunities (F14).

F2: Financing enterprises: Companies have good access to bank loans (F21); credit terms of banks are acceptable to companies (F22); the price of loans is acceptable to firms (F23); banks have a positive impact on the quality of the business environment (F24).

F3: Legal environment: I rate the level of legislation in business as good (F31); the commercial justice system works well (F32); law enforcement is good in our country (F33); the legislative environment in our country is stable (F34).

F4: Quality of education: I rate higher education in our country as good quality (F41); I evaluate the secondary school education as a quality one (F42); the state can prepare quality people for us (F43); school graduates have good knowledge and skills (F44).

F5: Infrastructure in the area of research and development: $R \& D$ infrastructure in our country is well built (F51); state support for R\&D in the country is at a good level (F52); R\&D results in our country help entrepreneurs; government support for R\&D has an upward trend (F54).

F6: Family environment: Family environment motivates people to do business (F61); it is easier to do business if one of the close relatives is doing business (F62); in the family, I have gained a lot of knowledge that helps me do business (F63); my family helps me do business (F64).

F7: Competitive environment: The risk of new competitors entering the sector in which I operate is appropriate (F71); the intensity of competition in the 
Table 1 Evaluation of indicators of macroeconomic environment

\begin{tabular}{|c|c|c|c|c|c|}
\hline F11 & $\mathrm{T}+\mathrm{S}$ & $\mathrm{C}+\mathrm{M}+\mathrm{A}$ & $\mathrm{F} 12$ & $\mathrm{~T}+\mathrm{S}$ & $\mathrm{C}+\mathrm{M}+\mathrm{A}$ \\
\hline $\mathrm{A} 1+\mathrm{A} 2$ & 136 & 101 & $\mathrm{~A} 1+\mathrm{A} 2$ & 131 & 100 \\
\hline$[\%]$ & 52.7 & 50.2 & {$[\%]$} & $50.8 \%$ & $49.8 \%$ \\
\hline V3 & 41 & 42 & $\mathrm{~V} 3$ & 58 & 54 \\
\hline $\mathrm{A} 4+\mathrm{A} 5$ & 81 & 58 & $\mathrm{~A} 4+\mathrm{A} 5$ & 69 & 47 \\
\hline [\%] & 31.4 & 28.9 & {$[\%]$} & $26.7 \%$ & $23.4 \%$ \\
\hline \multicolumn{2}{|c|}{ Chi-square } & 1.937 & \multicolumn{2}{|c|}{ Chi-square } & 1.419 \\
\hline \multicolumn{2}{|c|}{ P-value } & 0.379 & \multicolumn{2}{|c|}{ P-value } & 0.492 \\
\hline F13 & $\mathrm{T}+\mathrm{S}$ & $\mathrm{C}+\mathrm{M}+\mathrm{A}$ & F14 & $\mathrm{T}+\mathrm{S}$ & $\mathrm{C}+\mathrm{M}+\mathrm{A}$ \\
\hline $\mathrm{A} 1+\mathrm{A} 2$ & 78 & 62 & $\mathrm{~A} 1+\mathrm{A} 2$ & 80 & 76 \\
\hline$[\%]$ & 30.2 & 30.8 & {$[\%]$} & 31.0 & 37.8 \\
\hline V3 & 108 & 87 & V3 & 77 & 67 \\
\hline $\mathrm{A} 4+\mathrm{A} 5$ & 72 & 52 & $\mathrm{~A} 4+\mathrm{A} 5$ & 101 & 58 \\
\hline [\%] & 27.9 & 25.9 & [\%] & 39.1 & 28.9 \\
\hline \multicolumn{2}{|c|}{ Chi-square } & 0.240 & \multicolumn{2}{|c|}{ Chi-square } & 5.431 \\
\hline \multicolumn{2}{|c|}{ P-value } & 0.886 & \multicolumn{2}{|c|}{ P-value } & 0.049 \\
\hline
\end{tabular}

industry in which I operate is normal (F72); my customers accept the prices of my products and services (F73); my suppliers demand reasonable prices for their products and services (F74).

F8: Quality of business environment: The business environment in our country is of good quality and suitable for business (F81); business environment in our country is reasonably risky and allows business (F82); conditions for doing business in our country have improved in the last five years (F83); business environment in our country is suitable for starting a business (F84).

The following hypotheses have been formulated to meet the main objective of the article:

H: There are statistically significant differences in the perception of the macroeconomic environment (H1); business finance (H2); legislative environment (H3); quality of education (H4); R\&D infrastructure (H5); family environment (H6), competitive environment ( $\mathrm{H}^{2}$ ) and quality of business environment (H8) among selected groups of respondents (1st group: transport and services; 2nd group: construction; production and agriculture).

Statistically significant differences between selected groups of SMEs by national economy were compared using the Pearson statistics at a significance level of $5 \%$. If the calculated p-value was less than 5\% [25], an alternative statistical hypothesis of significant differences in the number of respondents to the claim was accepted. The calculations were performed using free software (www.socscistatistics. com/tests). Statistically significant differences in individual reactions were examined by the Z-score. The calculations were performed using free software (www.socscistatistics. com/tests/ztest/Default2.aspx).
The structure of the sample according to nationality: CR (312) and SR (329). The structure of the sample according to the size of the company was as follows (CR/ SR): micro (258/234), small (43/71) and medium (11/24) of the companies in the Czech Republic. The questionnaires were responded to (CR/SR): by $236 / 251$ of men's and $76 / 78$ women's. One of the factors was also the age of the company. Most respondents have had his business for more than 10 years (CR/SR: 208/147), 48/78 of entrepreneurs 5-10 years and the rest (56/104) of the entrepreneurs have operated their business 1-5 years. The survey involved all regions of the Czech Republic and the Slovak Republic. Regions representation of Czech Republic was as follows: Zlin Region (49), Moravian-Silesian Region (17), Olomouc Region (26), South Moravian Region (22), Liberec Region (28), Prague (17), Pardubice (17), Pilsen Region (22), Central Region (14), Hradec Kralove (17), Highlands (25), South Region (16), Usti Region (27) and Karlovy Vary (15). Regions representation of Slovak Republic was as follows: Presov Region (76), Kosice region (75), Bratislava region (56), Banska Bystrica region (30), Zilina region (28), Trnava region (27), Trencin region (20), Nitra region (17). Education (CR/SR): university education (127/224), higher education (135/95) and higher education without graduation (50/10). Questionnaires were addressed to entrepreneurs from different areas of the economy (CR/SR): 109/122 were from service companies, 73/69 were from commercial companies, 53/51 from manufacturing companies, 29/39 from the construction, 19/11 from transportation, 9/20 from agriculture and the rest belonged to "other" (industry not mentioned in the questionnaire). 
Table 2 Evaluation of indicators of financing enterprises

\begin{tabular}{|c|c|c|c|c|c|}
\hline F21 & $\mathrm{T}+\mathrm{S}$ & $\mathrm{C}+\mathrm{M}+\mathrm{A}$ & $\mathrm{F} 22$ & $\mathrm{~T}+\mathrm{S}$ & $\mathrm{C}+\mathrm{M}+\mathrm{A}$ \\
\hline $\mathrm{A} 1+\mathrm{A} 2$ & 77 & 57 & $\mathrm{~A} 1+\mathrm{A} 2$ & 98 & 65 \\
\hline$[\%]$ & 29.8 & 28.4 & [\%] & 38.0 & 32.3 \\
\hline V3 & 58 & 48 & V3 & 70 & 58 \\
\hline $\mathrm{A} 4+\mathrm{A} 5$ & 123 & 96 & $\mathrm{~A} 4+\mathrm{A} 5$ & 90 & 78 \\
\hline [\%] & 47.7 & 47.8 & [\%] & 34.9 & 38.8 \\
\hline \multicolumn{2}{|c|}{ Chi-square } & 0.181 & \multicolumn{2}{|c|}{ Chi-square } & 1.610 \\
\hline \multicolumn{2}{|c|}{ P-value } & 0.913 & \multicolumn{2}{|c|}{ P-value } & 0.447 \\
\hline $\mathrm{F} 23$ & $\mathrm{~T}+\mathrm{S}$ & $\mathrm{C}+\mathrm{M}+\mathrm{A}$ & $\mathrm{F} 24$ & $\mathrm{~T}+\mathrm{S}$ & $\mathrm{C}+\mathrm{M}+\mathrm{A}$ \\
\hline $\mathrm{A} 1+\mathrm{A} 2$ & 85 & 58 & $\mathrm{~A} 1+\mathrm{A} 2$ & 84 & 56 \\
\hline [\%] & 32.9 & 28.9 & [\%] & 32.6 & 27.9 \\
\hline V3 & 71 & 62 & V3 & 98 & 79 \\
\hline $\mathrm{A} 4+\mathrm{A} 5$ & 102 & 81 & $\mathrm{~A} 4+\mathrm{A} 5$ & 76 & 66 \\
\hline [\%] & 39.5 & 40.3 & [\%] & 29.5 & 32.8 \\
\hline \multicolumn{2}{|c|}{ Chi-square } & 1.054 & \multicolumn{2}{|c|}{ Chi-square } & 1.258 \\
\hline \multicolumn{2}{|c|}{ P-value } & 0.591 & \multicolumn{2}{|c|}{ P-value } & 0.526 \\
\hline
\end{tabular}

Table 3 Evaluation of indicators of legal environment

\begin{tabular}{|c|c|c|c|c|c|}
\hline F31 & $\mathrm{T}+\mathrm{S}$ & $\mathrm{C}+\mathrm{M}+\mathrm{A}$ & F32 & $\mathrm{T}+\mathrm{S}$ & $\mathrm{C}+\mathrm{M}+\mathrm{A}$ \\
\hline $\mathrm{A} 1+\mathrm{A} 2$ & 184 & 137 & $\mathrm{~A} 1+\mathrm{A} 2$ & 147 & 93 \\
\hline [\%] & 71.3 & 68.2 & [\%] & 57.0 & 46.3 \\
\hline V3 & 27 & 24 & V3 & 73 & 71 \\
\hline $\mathrm{A} 4+\mathrm{A} 5$ & 47 & 40 & $\mathrm{~A} 4+\mathrm{A} 5$ & 38 & 37 \\
\hline [\%] & 18.2 & 19.9 & [\%] & 14.7 & 18.4 \\
\hline \multicolumn{2}{|c|}{ Chi-square } & 0.551 & \multicolumn{2}{|c|}{ Chi-square } & 5.541 \\
\hline \multicolumn{2}{|c|}{ P-value } & 0.759 & \multicolumn{2}{|c|}{$\mathrm{P}$-value } & 0.047 \\
\hline F33 & $\mathrm{T}+\mathrm{S}$ & $\mathrm{C}+\mathrm{M}+\mathrm{A}$ & F34 & $\mathrm{T}+\mathrm{S}$ & $\mathrm{C}+\mathrm{M}+\mathrm{A}$ \\
\hline $\mathrm{A} 1+\mathrm{A} 2$ & 161 & 125 & $\mathrm{~A} 1+\mathrm{A} 2$ & 139 & 106 \\
\hline [\%] & 62.4 & 62.2 & [\%] & 53.9 & 52.7 \\
\hline V3 & 57 & 45 & V3 & 59 & 50 \\
\hline $\mathrm{A} 4+\mathrm{A} 5$ & 40 & 31 & $\mathrm{~A} 4+\mathrm{A} 5$ & 60 & 45 \\
\hline [\%] & 15.5 & 15.4 & [\%] & 23.3 & 22.4 \\
\hline \multicolumn{2}{|c|}{ Chi-square } & 0.005 & \multicolumn{2}{|c|}{ Chi-square } & 0.256 \\
\hline \multicolumn{2}{|c|}{ P-value } & 0.997 & \multicolumn{2}{|c|}{ P-value } & 0.879 \\
\hline
\end{tabular}

\section{Results}

The total number of respondents in the sectors of the national economy, such as transport, services, construction, manufacturing and agriculture was 459 SMEs. Of these, 216 were from the Czech Republic and 243 from Slovakia; by national economy: $258(\mathrm{~T}+\mathrm{S})$ and $201(\mathrm{C}+\mathrm{M}+\mathrm{A})$; by sex: 356 men and 103 women; by education: 247 higher education, 212 other education; by time of business: 258 more than 10 years, 201 less than 10 years.

Table 1 summarizes the perception of the macroeconomic environment by the SME respondents by sector of the national economy.

The structure of respondents' responses to the current level of basic macroeconomic variables (GDP, employment, inflation) supports entrepreneurship and creates interesting business opportunities (F14) is statistically significant (P-value of the Chi-square test is 0.049). There are statistically significant differences in positive responses (V4 + V5) in the perception of the indicator "F14" according to selected groups of respondents (P-value of Z-score (2.299) is 0.029$)$. The hypothesis $\mathrm{H} 1$ was partially accepted.

Table 2 summarizes the perception of the SME financing by enterprises by sector of the national economy.

The structure of respondents' responses to business finance indicators (F21, F22, F23, F24) is not statistically significant (P-values of the Chi-square test are greater than the level of significance - 0.05). There are no statistically significant differences in the perception of business finance indicators by selected groups of respondents (P-values are greater than 0.05 ). The hypothesis $\mathrm{H} 2$ was rejected. 
Table 4 Evaluation of indicators of quality of education

\begin{tabular}{|c|c|c|c|c|c|}
\hline F41 & $\mathrm{T}+\mathrm{S}$ & $\mathrm{C}+\mathrm{M}+\mathrm{A}$ & F42 & $\mathrm{T}+\mathrm{S}$ & $\mathrm{C}+\mathrm{M}+\mathrm{A}$ \\
\hline $\mathrm{A} 1+\mathrm{A} 2$ & 100 & 70 & $\mathrm{~A} 1+\mathrm{A} 2$ & 120 & 84 \\
\hline [\%] & 38.8 & 34.8 & [\%] & 46.5 & 41.8 \\
\hline V3 & 63 & 55 & V3 & 61 & 52 \\
\hline $\mathrm{A} 4+\mathrm{A} 5$ & 95 & 76 & $\mathrm{~A} 4+\mathrm{A} 5$ & 77 & 65 \\
\hline [\%] & 36.8 & 37.8 & [\%] & 29.8 & 32.3 \\
\hline \multicolumn{2}{|c|}{ Chi-square } & 0.882 & \multicolumn{2}{|c|}{ Chi-square } & 1.021 \\
\hline \multicolumn{2}{|c|}{ P-value } & 0.643 & \multicolumn{2}{|c|}{ P-value } & 0.600 \\
\hline F43 & $\mathrm{T}+\mathrm{S}$ & $\mathrm{C}+\mathrm{M}+\mathrm{A}$ & F44 & $\mathrm{T}+\mathrm{S}$ & $\mathrm{C}+\mathrm{M}+\mathrm{A}$ \\
\hline $\mathrm{A} 1+\mathrm{A} 2$ & 178 & 122 & $\mathrm{~A} 1+\mathrm{A} 2$ & 134 & 104 \\
\hline [\%] & 69.0 & 60.7 & [\%] & 51.9 & 51.7 \\
\hline V3 & 47 & 46 & V3 & 59 & 55 \\
\hline $\mathrm{A} 4+\mathrm{A} 5$ & 33 & 33 & $\mathrm{~A} 4+\mathrm{A} 5$ & 65 & 42 \\
\hline [\%] & 12.8 & 16.4 & [\%] & 25.2 & 20.9 \\
\hline \multicolumn{2}{|c|}{ Chi-square } & 3.438 & \multicolumn{2}{|c|}{ Chi-square } & 1.815 \\
\hline \multicolumn{2}{|c|}{ P-value } & 0.179 & \multicolumn{2}{|c|}{ P-value } & 0.403 \\
\hline
\end{tabular}

Table 5 Evaluation of indicators of infrastructure in the area of research and development

\begin{tabular}{|c|c|c|c|c|c|}
\hline F51 & $\mathrm{T}+\mathrm{S}$ & $\mathrm{C}+\mathrm{M}+\mathrm{A}$ & F52 & $\mathrm{T}+\mathrm{S}$ & $\mathrm{C}+\mathrm{M}+\mathrm{A}$ \\
\hline $\mathrm{A} 1+\mathrm{A} 2$ & 110 & 81 & $\mathrm{~A} 1+\mathrm{A} 2$ & 111 & 85 \\
\hline$[\%]$ & 42.6 & 40.3 & [\%] & 43.0 & 42.3 \\
\hline $\mathrm{V} 3$ & 99 & 79 & $\mathrm{~V} 3$ & 103 & 73 \\
\hline $\mathrm{A} 4+\mathrm{A} 5$ & 49 & 41 & $\mathrm{~A} 4+\mathrm{A} 5$ & 44 & 43 \\
\hline [\%] & 19.0 & 20.4 & [\%] & 17.1 & 21.4 \\
\hline \multicolumn{2}{|c|}{ Chi-square } & 0.287 & \multicolumn{2}{|c|}{ Chi-square } & 1.519 \\
\hline \multicolumn{2}{|c|}{ P-value } & 0.866 & \multicolumn{2}{|c|}{$\mathrm{P}$-value } & 0.468 \\
\hline F53 & $\mathrm{T}+\mathrm{S}$ & $\mathrm{C}+\mathrm{M}+\mathrm{A}$ & F54 & $\mathrm{T}+\mathrm{S}$ & $\mathrm{C}+\mathrm{M}+\mathrm{A}$ \\
\hline $\mathrm{A} 1+\mathrm{A} 2$ & 73 & 54 & $\mathrm{~A} 1+\mathrm{A} 2$ & 69 & 51 \\
\hline$[\%]$ & 28.3 & 26.9 & [\%] & 26.7 & 25.4 \\
\hline $\mathrm{V} 3$ & 124 & 87 & $\mathrm{~V} 3$ & 117 & 103 \\
\hline $\mathrm{A} 4+\mathrm{A} 5$ & 61 & 60 & $\mathrm{~A} 4+\mathrm{A} 5$ & 72 & 47 \\
\hline$[\%]$ & 23.6 & 29.9 & [\%] & 27.9 & 23.4 \\
\hline \multicolumn{2}{|c|}{ Chi-square } & 2.296 & \multicolumn{2}{|c|}{ Chi-square } & 1.792 \\
\hline \multicolumn{2}{|c|}{ P-value } & 0.317 & \multicolumn{2}{|c|}{ P-value } & 0.408 \\
\hline
\end{tabular}

Table 3 summarizes the perception of the legislative environment by $\mathrm{S}$ the ME respondents by sector of the national economy.

The structure of respondents' responses to the business justice system works well (F32) is statistically significant (P-value of the Chi-square test is 0.047). There are statistically significant differences in positive responses (V4 + V5) in the perception of the indicator "F32" according to selected groups of respondents (P-value of Z-score (2.184) is 0.039 ). The hypothesis H3 was partially accepted.

Table 4 summarizes the perception of the quality of education by the SME respondents by sector of the national economy.
The structure of respondents' responses to the quality of education indicators (F41, F42, F43, F44) is not statistically significant (P-values of the Chi-square test are greater than the level of significance - 0.05). There are no statistically significant differences in the perception of indicators of quality of education by selected groups of respondents (P-values of Z-score are greater than 0.05). Hypothesis H4 was rejected.

Table 5 summarizes the perception of R\&D infrastructure by the SME respondents by sector of the national economy.

The structure of respondents' answers to the infrastructure indicators in the area of research and 
Table 6 Evaluation of indicators of family environment

\begin{tabular}{|c|c|c|c|c|c|}
\hline F61 & $\mathrm{T}+\mathrm{S}$ & $\mathrm{C}+\mathrm{M}+\mathrm{A}$ & F62 & $\mathrm{T}+\mathrm{S}$ & $\mathrm{C}+\mathrm{M}+\mathrm{A}$ \\
\hline $\mathrm{A} 1+\mathrm{A} 2$ & 55 & 39 & $\mathrm{~A} 1+\mathrm{A} 2$ & 31 & 30 \\
\hline [\%] & 21.3 & 19.4 & {$[\%]$} & 12.0 & 14.9 \\
\hline $\mathrm{V} 3$ & 53 & 38 & $\mathrm{~V} 3$ & 42 & 36 \\
\hline $\mathrm{A} 4+\mathrm{A} 5$ & 150 & 124 & $\mathrm{~A} 4+\mathrm{A} 5$ & 185 & 135 \\
\hline [\%] & 58.1 & 61.7 & {$[\%]$} & 71.7 & 67.2 \\
\hline \multicolumn{2}{|c|}{ Chi-square } & 0.594 & \multicolumn{2}{|c|}{ Chi-square } & 1.123 \\
\hline \multicolumn{2}{|c|}{ P-value } & 0.743 & \multicolumn{2}{|c|}{ P-value } & 0.540 \\
\hline F63 & $\mathrm{T}+\mathrm{S}$ & $\mathrm{C}+\mathrm{M}+\mathrm{A}$ & F64 & $\mathrm{T}+\mathrm{S}$ & $\mathrm{C}+\mathrm{M}+\mathrm{A}$ \\
\hline $\mathrm{A} 1+\mathrm{A} 2$ & 54 & 39 & $\mathrm{~A} 1+\mathrm{A} 2$ & 22 & 15 \\
\hline$[\%]$ & 20.9 & 19.4 & [\%] & 8.5 & 7.5 \\
\hline V3 & 57 & 34 & V3 & 24 & 22 \\
\hline $\mathrm{A} 4+\mathrm{A} 5$ & 147 & 128 & $\mathrm{~A} 4+\mathrm{A} 5$ & 212 & 164 \\
\hline [\%] & 57.0 & 63.7 & [\%] & 82.2 & 81.6 \\
\hline \multicolumn{2}{|c|}{ Chi-square } & 2.505 & \multicolumn{2}{|c|}{ Chi-square } & 0.467 \\
\hline \multicolumn{2}{|c|}{ P-value } & 0.285 & \multicolumn{2}{|c|}{$\mathrm{P}$-value } & 0.791 \\
\hline
\end{tabular}

Table 7 Evaluation of indicators of competitive environment

\begin{tabular}{|c|c|c|c|c|c|}
\hline F71 & $\mathrm{T}+\mathrm{S}$ & $\mathrm{C}+\mathrm{M}+\mathrm{A}$ & F72 & $\mathrm{T}+\mathrm{S}$ & $\mathrm{C}+\mathrm{M}+\mathrm{A}$ \\
\hline $\mathrm{A} 1+\mathrm{A} 2$ & 53 & 42 & $\mathrm{~A} 1+\mathrm{A} 2$ & 49 & 49 \\
\hline$[\%]$ & 20.5 & 20.9 & [\%] & 19.0 & 24.4 \\
\hline V3 & 27 & 36 & $\mathrm{~V} 3$ & 33 & 22 \\
\hline $\mathrm{A} 4+\mathrm{A} 5$ & 178 & 123 & $\mathrm{~A} 4+\mathrm{A} 5$ & 176 & 130 \\
\hline [\%] & 69.0 & 61.2 & [\%] & 68.2 & 64.7 \\
\hline \multicolumn{2}{|c|}{ Chi-square } & 5.617 & \multicolumn{2}{|c|}{ Chi-square } & 2.068 \\
\hline \multicolumn{2}{|c|}{ P-value } & 0.042 & \multicolumn{2}{|c|}{ P-value } & 0.355 \\
\hline F73 & $\mathrm{T}+\mathrm{S}$ & $\mathrm{C}+\mathrm{M}+\mathrm{A}$ & F74 & $\mathrm{T}+\mathrm{S}$ & $\mathrm{C}+\mathrm{M}+\mathrm{A}$ \\
\hline $\mathrm{A} 1+\mathrm{A} 2$ & 24 & 30 & $\mathrm{~A} 1+\mathrm{A} 2$ & 41 & 28 \\
\hline$[\%]$ & 9.3 & 14.9 & {$[\%]$} & 15.9 & 13.9 \\
\hline $\mathrm{V} 3$ & 24 & 23 & $\mathrm{~V} 3$ & 49 & 30 \\
\hline $\mathrm{A} 4+\mathrm{A} 5$ & 210 & 148 & $\mathrm{~A} 4+\mathrm{A} 5$ & 168 & 143 \\
\hline [\%] & 81.4 & 73.6 & [\%] & 65.1 & 71.1 \\
\hline \multicolumn{2}{|c|}{ Chi-square } & 4.415 & \multicolumn{2}{|c|}{ Chi-square } & 1.981 \\
\hline \multicolumn{2}{|c|}{ P-value } & 0.041 & \multicolumn{2}{|c|}{ P-value } & 0.371 \\
\hline
\end{tabular}

development (F51, F52, F53, F54) is not statistically significant (P-values of the Chi-square test are higher than the level of significance - 0.05). There are no statistically significant differences in the perception of infrastructure indicators in the area of research and development according to selected groups of respondents (P-values of Z-score are greater than 0.05). The hypothesis H5 was rejected.

Table 6 summarizes the perception of the family environment by the SME respondents by sector of the national economy.

The structure of respondents' responses to family environment indicators (F61, F62, F63, F64) is not statistically significant. There are no statistically significant differences in the perception of family environment indicators by selected groups of respondents (P-values of Z-scores are greater than 0.05). Hypothesis H6 was rejected.

Table 7 summarizes the perception of the competitive environment by the SME respondents by sector of the national economy.

The structure of respondents' responses to the risk of new competitors entering the SME industry (F71) and the fact that customers accept the prices OF products and services (F73) are statistically significant (F71: P-value of Chi-square test is 0.042 ; F73: P-value of Chi-square test is 0.041). There are statistically significant differences in positive responses (V4 + V5) in the perception of indicators "F71 and F73" according to selected groups of respondents 
Table 8 Evaluation of indicators of quality of business environment

\begin{tabular}{|c|c|c|c|c|c|}
\hline F81 & $\mathrm{T}+\mathrm{S}$ & $\mathrm{C}+\mathrm{M}+\mathrm{A}$ & $\mathrm{F} 82$ & $\mathrm{~T}+\mathrm{S}$ & $\mathrm{C}+\mathrm{M}+\mathrm{A}$ \\
\hline $\mathrm{A} 1+\mathrm{A} 2$ & 156 & 124 & $\mathrm{~A} 1+\mathrm{A} 2$ & 78 & 61 \\
\hline$[\%]$ & 60.5 & 61.7 & {$[\%]$} & 30.2 & 30.3 \\
\hline V3 & 36 & 36 & $\mathrm{~V} 3$ & 37 & 31 \\
\hline $\mathrm{A} 4+\mathrm{A} 5$ & 66 & 41 & $\mathrm{~A} 4+\mathrm{A} 5$ & 143 & 109 \\
\hline [\%] & 25.6 & 20.4 & [\%] & 47.7 & 47.8 \\
\hline \multicolumn{2}{|c|}{ Chi-square } & 2.458 & \multicolumn{2}{|c|}{ Chi-square } & 0.119 \\
\hline \multicolumn{2}{|c|}{ P-value } & 0.292 & \multicolumn{2}{|c|}{ P-value } & 0.942 \\
\hline F83 & $\mathrm{T}+\mathrm{S}$ & $\mathrm{C}+\mathrm{M}+\mathrm{A}$ & F84 & $\mathrm{T}+\mathrm{S}$ & $\mathrm{C}+\mathrm{M}+\mathrm{A}$ \\
\hline $\mathrm{A} 1+\mathrm{A} 2$ & 142 & 103 & $\mathrm{~A} 1+\mathrm{A} 2$ & 119 & 85 \\
\hline$[\%]$ & 55.0 & 51.2 & [\%] & 46.1 & 42.3 \\
\hline $\mathrm{V} 3$ & 45 & 42 & $\mathrm{~V} 3$ & 42 & 45 \\
\hline $\mathrm{A} 4+\mathrm{A} 5$ & 71 & 56 & $\mathrm{~A} 4+\mathrm{A} 5$ & 97 & 71 \\
\hline [\%] & 27.5 & 27.9 & [\%] & 37.6 & 35.3 \\
\hline \multicolumn{2}{|c|}{ Chi-square } & 1.021 & \multicolumn{2}{|c|}{ Chi-square } & 2.758 \\
\hline \multicolumn{2}{|c|}{ P-value } & 0.600 & \multicolumn{2}{|c|}{ P-value } & 0.252 \\
\hline
\end{tabular}

(F71: P-value of Z-score (1.979) is 0.044; F73: P-value of Z-score (1.991) is 0.047). The hypothesis $\mathrm{H} 7$ was partially accepted.

Table 8 summarizes the perception of the quality of the business environment by the SME respondents by sector of the national economy.

The structure of respondents' responses to business environment quality indicators (F81, F82, F83, F84) is not statistically significant (P-values of the Chi-square test are greater than the level of significance - 0.05). There are no statistically significant differences in the perception of business environment quality indicators by selected groups of respondents (P-values of Z-score are greater than 0.05). The hypothesis $\mathrm{H} 8$ was rejected.

\section{Discussion}

The results show that seven out of ten respondents agree (agree or fully agree) with the indicators of the competitive environment (entrepreneurs consider the risk of entry of competition in the business sector appropriate; intensity of competition in the industry is normal; customers accept prices for products and services; the adequacy of the prices of their suppliers' products and services). The findings concerning intensive competition as a factor that impacts business environment are consistent with previous studies [26-27].

On the other hand, six out of ten respondents disagree (totally disagree or disagree) with the legislative environment indicators (good level of business legislation; quality of the judicial system in the area of commercial law; law enforcement is good; stability of the legislative environment). The findings concerning the legislative environment as a factor that impacts business environment are consistent with previous study [28].
It has also been shown that entrepreneurs are of the opinion that the state is not able to prepare quality people for companies (more than $60 \%$ of respondents). Also, entrepreneurs think that school graduates do not have good knowledge and skills (more than 50\% of respondents).

A comparison of respondents' attitudes, divided into two groups according to the national economy sector, shows that there is no difference in perception of factors such as the family environment, the quality of the business environment, the quality of education, business financing and R\&D infrastructure.

On the other hand, differences in the assertion that the current value of macroeconomic indicators (GDP, unemployment and others) support entrepreneurship have been shown. Up to $39.1 \%$ of the SMEs in the transport and services sectors agree with this statement, compared to $28.9 \%$ of the SMEs in the construction, manufacturing and agriculture sectors. There are also significant differences in the argument that the judicial system in commercial law works well. Up to $57.0 \%$ of the SMEs in the transport and services sector disagree with this statement, compared to $46.3 \%$ of the SMEs in the construction, manufacturing and agriculture sectors.

The greatest lack of consistency among the selected SME groups is when assessing the factor of the competitive environment. The SMEs in the transport and services sectors are more in agreement with the claim (81.4\%) that the customers accept the prices of products and services compared to the SMEs in the construction, manufacturing and agriculture sectors (73.6\%). The findings concerning the comparison of the competitive environment between the $\mathrm{T}+\mathrm{S}$ (the transport and service sector) and the $\mathrm{C}+\mathrm{M}+\mathrm{A}$ (the construction, manufacturing and agriculture sector) are not consistent with the study [29]. The results of this research are less consistent. 


\section{Conclusions}

The aim of the article was to identify differences in the perception of selected factors that determine the business environment among selected groups of small and mediumsized enterprises (SMEs) according to the sector of the national economy.

The results showed interesting findings. The SMEs in transport and services perceive the competitive environment as more acceptable than the SMEs in construction, construction and agriculture. In addition, the SMEs in transport and services are of the opinion that customers accept the prices of their products and services to a greater extent than the SMEs in construction, manufacturing and agriculture. There are also significant differences between selected groups of the SMEs in assessing the quality of the judicial system in commercial law and the view that the current level of macroeconomic indicators (GDP, unemployment, etc.) promotes entrepreneurship and creates interesting business opportunities. The sector of the national economy is not an important criterion when assessing the financing of businesses; family environment; R\&D infrastructures; the quality of the business environment and the quality of education.

The authors are aware of the limitations of the case study (e.g. the local nature of the study - 2 Central European countries; the number of SMEs - only 459; verification of results using one methodology; application of selected statistical methods). The authors believe that the paper may bring some interesting findings and new incentives for further research and discussion on the cross-sectoral assessment of the business environment quality and its important factors.

The future research will focus on comparing other factors that determine the quality of the business environment among selected groups of SMEs. Those are mainly the areas of monetary policy and interest rates; state regulation and business support; state bureaucracy; availability of human capital; private-public cooperation; media and communication environment, or narrower business environment. It is assumed that the attitudes of SMEs towards the above factors will bring different perceptions.

\section{References}

[1] CEPEL, M., STASIUKYNAS, A., KOTASKOVA, A., DVORSKY, J. Business environment quality index in the SME segment. Journal of Competitiveness [online]. 2018, 10(2), p. 21-40. ISSN 1804-171X. Available from: https://dx.doi. org/10.7441/joc.2018.02.02

[2] BUGANOVA, K., MORICOVA, V. Innovation of education in risk and crisis management. Turkish Online Journal of Educational Technology. 2017, INTE-2017, p. 177-182. ISSN 2146-7242.

[3] HAVIERNIKOVA, K., KORDOS, M. Selected risks perceived by SMEs related to sustainable entrepreneurship in case of engagement into cluster cooperation. Entrepreneurship and Sustainability Issues [online]. 2019, 6(4), p. 1680-1693. eISSN 2345-0282. Available from: https://doi.org/10.9770/jesi.2019.6.4(9)

[4] HUDAKOVA, M., DVORSKY, J. Analysis of the market risk sources in the small and medium-sized enterprises of transport. Communications - Scientific Letters of the University of Zilina [online]. 2019, 21(4), p. 97-103. ISSN 1335-4205, eISSN 2585-7878. Available from: http://komunikacie.uniza.sk/index.php/communications/article/ view/1524

[5] KLJUCNIKOV, A., BELAS, J., KOZUBIKOVA, L., PASEKOVA, P. The entrepreneurial perception of SME business environment quality in the Czech Republic. Journal of Competitiveness [online]. 2016, 8(1), p. 66-78. ISSN 1804-171X. Available from: https://dx.doi.org/10.7441/joc.2016.01.05

[6] DVORSKY, J., PETRAKOVA, Z., POLACH, J. Assessing the market, financial, and economic risk sources by Czech and Slovak SMEs. International Journal of Entrepreneurial Knowledge [online]. 2019, 7(2), p. 30-40. ISSN $2336-2960$. Available from: https://doi.org/10.2478/ijek-2019-0008

[7] TERSKIKH, V., KATARGIN, V., MOROZOVA, N. Planning and managing resources of transport enterprises. MATEC Web of Conferences [online]. 2018, 239, 04023. eISSN 2261-236X. Available from: https://dx.doi.org/10.1051/ matecconf/201823904023

[8] FORMANKOVA, S., VAJCNEROVA, I, RYGlOVA, K., CHLADKOVA, H., STOJANOVA, H., ANDRASKO, I. Achieving quality and sustainability in the Czech business environment. Newcastle upon Tyne: Cambridge Scholars Publishing, 2018. ISBN 9781527505452.

[9] OLAH, J., VIRGLEROVA, Z., POPP, J., KLIESTIKOVA, J., KOVACS, S. The assessment of non-financial risk sources of SMES in the V4 countries and Serbia. Sustainability [online]. 2019, 11(17), p. 1-19. eISSN2071-1050. Available from: https://doi.org/10.3390/su11174806

[10] DVORSKY, J., SCHONFELD, J., KOTASKOVA, A., PETRAKOVA, Z. Evaluation of important credit risk factors in the SME segment. Journal of International Studies [online]. 2018, 11(3), p. 204-216. ISSN 2071-8330, eISSN $2306-3483$. Available from: https://dx.doi.org/10.14254/2071-8330.2018/11-3/17 
[11] KOZUBIKOVA, L., KOTASKOVA, A., DVORSKY, J., KLJUCNIKOV, A. The impact of political factors' perception on suitability of international business environment: the case of startups. Economics and Sociology [online]. 2019, 12(1), p. 61-79. ISSN 2071-789X. Available from: https://dx.doi.org/10.14254/2071-789X.2019/12-1/3

[12] HUDAKOVA, M., MASAR, M., BUGANOVA, K. Assessment of the financial risks of the small and medium-sized enterprises in Slovakia. In: 34th International Scientific Conference on Economic and Social Development - 18th International Social Congress ISC-2018 : proceedings. 2018. p. 505-513.

[13] CIVELEK, M., KLJUCNIKOV, A., DOBROVIC, J., HUDAKOVA, M. A model of measurement of the quality of business environment in SME segment. Journal of International Studies [online]. 2016, 9(2), p. 90-102. ISSN 2071-8330, eISSN 2306-3483. Available from: https://dx.doi.org/10.14254/2071-8330.2016/9-2/6

[14] VITURKA, M. The quality of business environment, regional competitiveness and regional development strategy of the Czech Republic (in Czech). Prague: Grada, 2010. ISBN 9788024736389.

[15] HUDAKOVA, M., MASAR, M., LUSKOVA, M., PATAK, M. R. The dependence of perceived business risks on the size of SMEs. Journal of Competitiveness [online]. 2018, 10(4), p. 54-69. ISSN 1804-171X. Available from: https://doi.org/10.7441/joc.2018.04.04

[16] BELAS, J., GAVUROVA, B., SCHONFELD, J., ZVARIKOVA, K., KACERAUSKAS, T. Social and economic factors affecting the entrepreneurial intention of university students. Transformations in Business and Economics. 2017, 16(3), p. 220-239. ISSN 1648-4460.

[17] CHLADKOVA, H. Selected approaches to the business environment evaluation. Acta Universitatis Agriculturae et Silviculturae Mendelianae Brunensis. 2015, 63(2), p. 515-523. ISSN:1211-8516.

[18] EISLER, J. Economics of transport services and the business of transport (in Czech). Praha: Oeconomica, 2004. ISBN 8024507722.

[19] FABUS, M., CSABAY, M. State aid and investment: case of Slovakia. Entrepreneurship and Sustainability Issues [online]. 2018, 6(2), p. 480-488. eISSN 2345-0282. Available from: https://dx.doi.org/10.9770/jesi.2018.6.2(1)

[20] SUROVEC, P. Operation and economics of road transport I. (in Czech). Ostrava: Technical University of Ostrava, Faculty of Mechanical Engineering, 2000. ISBN 80-7078-735-X.

[21] NOVACK, R. A., GIBSON, B. J., SUZUKI, Y., COYLE, J. J. Transportation: a global supply chain perspective. 9. ed. Australia: Cengage, 2019. ISBN 978-1-337-40664-2.

[22] TUCKOVA, Z. Economics of services (in Czech). Praha: Wolters Kluwer, 2013. ISBN 978-80-7478-006-6.

[23] BRYSON, J. R.; DANIELS, P. W. The handbook of service industries. USA: Edward Elgar Publishing, Inc., 2007. ISBN 978-1-84064-948-2.

[24] MARTINEZ-FERNANDEZ, C., MILES, I., WEYMAN, T. The knowledge economy at work: skills and innovation in knowledge intensive service activities. Cheltenham: Edward Elgar, 2011. ISBN 9781847200495.

[25] HAIR, J. F., ANDERSON, R. E., BABIN, B. J., BLACK, W. C. Multivariate data analysis: a global perspective. 7. ed. Upper Saddle River, NJ: Pearson Prentice Hall, 2010. ISBN 978-1-292-02190-4.

[26] CERA, G., BELAS, J., STRNAD, Z. Important factors which predict entrepreneur's perception in business risk. Problems and Perspectives in Management [online]. 2019, 17(2), p. 415-429. ISSN 1810-5467, eISSN 1727-7051. Available from: https://dx.doi.org/10.21511/ppm.17(2).2019.32

[27] DELERUE, H., PEREZ, M. Unilateral commitment in alliances: an optional behaviour. Journal of Management Development [online]. 2009, 28(2), p. 134-149. ISSN 0262-1711. Available from: https://doi.org/10.1108/02621710910932098

[28] ARDIC, O. P., MYLENKO, N., SALTANE, V. Access to finance by small and medium enterprises: a cross-country analysis with a new data set. Pacific Economic Review [online]. 2012, 17(4), p. 491-513. eISSN 1468-0106. Available from: https://dx.doi.org/10.1111/j.1468-0106.2012.00596.x

[29] ACAR, E., YASEMIN, G. Prediction of risk perception by owners' psychological traits in small building contractors. Construction Management and Economics [online]. 2011, 29(8), p. 841-852. ISSN 0144-6193, eISSN 1466-433X. Available from: https://dx.doi.org/10.1080/01446193.2011.611521 